\title{
LABOR LAW IN THE SUPREME COURT: 1964 TERM
}

\section{CLYDE SUMMERS $\dagger$}

LABOR law cases are, to all except the myopic labor lawyer, a subordinate part of the Supreme Court's work. The Court's primary attention is focused on its role in stripping away remnants of racial discrimination and segregation, ${ }^{1}$ reconstructing rotted-out state legislatures, ${ }^{2}$ sensitizing law enforcement to the rights of the accused, ${ }^{3}$ and removing restraints on the free market of ideas. ${ }^{4}$ These are social and political issues of the first magnitude, robed in the legal garb of "cases and controversies," and brought to the judicial forum for settlement. The Court's decisions significantly reshape our institutions, for it often becomes the final arbiter directing resolution of these issues. Even if Senator Dirksen's amendment $^{5}$ is adopted, for example, it can never restore the rural control of state legislatures.

By comparison, labor law cases pose relatively simple problems. Although they raise crucial issues of union-management relations and the rights of individuals within this collective structure, the Court has three major statutes for guidance-the Norris-LaGuardia Act; ${ }^{6}$ the National Labor Relations Act, twice substantially amended; ${ }^{7}$ and the Labor Management Reporting and Disclosure Act. ${ }^{8}$ The Court's function is to follow the will of Congress; its choices are confined by the words of the statutes; its decisions are subject to legislative review. And in a major segment of these cases the Court has the aid of the National Labor Relations Board which serves as an intermediary to evolve and project solutions which will fulfill the statutory purpose. Rarely do labor cases

+ Professor of Law, Yale University.

1. See, for example, McLaughlin v. Florida, 379 U.S. 184 (1964); Heart of Atlanta Motel, Inc. v. U.S., 379 U.S. 241 (1964).

2. See, for example, Scott v. Germano, 381 U.S. 407 (1965); Jordan v. Silver, 381 U.S. 415 (1965); Hughes v. WMAC, Inc., 379 U.S. 694 (1965).

3. See, for example, Boles v. Stevenson, 379 U.S. 43 (1964); Estes v. Texas, 381 U.S. 532 (1965); Griffin v. California, 380 U.S. 609 (1964).

4. See, for example, Dombrowski v. Pfister, 380 U.S. 479 (1965); Lamont v. Postmaster General, 381 U.S. 301 (1965).

5. S.J. Res. 103, 89th Cong., 1st Sess. (1965).

6. 47 Stat. 70 (1932), as amended, 29 U.S.C. $\S 101-15$ (1958).

7. 49 Stat. 449 (1935), as amended 61 Stat. 136 (1947), as amended 73 Stat. 542 (1959), as amended 29 U.S.C. §§ 151-68 (1964).

8. 73 Stat. 519, 29 U.S.C. $\S \$ 401$ et seq. (1964). 
require constitutional determinations-United States $v$. Brown ${ }^{9}$ striking down as a bill of attainder the rather irrelevant prohibition against communists and former communists holding union office is an exception -and only occasionally do constitutional overtones give special vibrance to statutory words. ${ }^{10}$ These apart, the Court is the servant, not the master of legislative will.

This comparison could give comfort to the labor lawyers and to others -if only it were more than half true. But concern with the Supreme Court's labor decisions goes beyond the journeyman lawyer's interest in advising clients and predicting results. Decisions during the past term make plain that the Court's role in this area is not so circumscribed; that here, as in other areas, the Court shapes social institutions with little or no legislative guidance.

The Court, during the 1964-65 term, confronted a grab bag of issues varying from the right of an individual to sue for breach of a collective agreement without first seeking recourse in the grievance procedure ${ }^{11}$ to the form of the ballot in representation elections under the Railway Labor Act. ${ }^{12}$ Detailed discussion here, however, is largely limited to its disposal of four major problems. The immediate and more prosaic purposes is to sketch the changes these decisions work in the body of substantive law and the impact of those changes on collective bargaining structures. The larger purpose is, through these and the other cases, to suggest some of the reasons for the Court's commanding role in the lawmaking process, not as ideally conceived, but as realistically practiced.

\section{The Content of Collective Bargaining-The Fibreboard Case}

The most constructive contribution of the Court was its projection in the Fibreboard case $^{13}$ of a workable standard for determining what subjects fall within the reach of mandatory bargaining. The employer, near the end of the contract term, announced to the union representing a unit of maintenance employees that because of cost considerations it had made a definite decision to subcontract all of its maintenance work to an independent contractor. The employer bargained with the union about termination pay for the employees dismissed, but this was not enough. The employer must bargain with the union in advance about

9. 381 U.S. 437 (1965).

10. See, for example, NLRB v. Fruit and Vegetable Packers Local 760, 377 U.S. 58 (1964); International Ass'n of Machinists v. Street, 367 U.S. 740 (1961).

11. Republic Steel Corp. v. Maddox, 379 U.S. 650 (1964).

12. Brotherhood of Railway and Steamship Clerks v. Association for the Benefit of Non-Contract Employees, 380 U.S. 650 (1965).

13. Fibreboard Paper Products Corp. v. NLRB, 379 U.S. 203 (1964). 
its decision to subcontract. Because Fibreboard had failed to do so the NLRB ordered it to resume the maintenance operation, reinstate the employees laid off, and fulfill its statutory obligation to bargain. ${ }^{14}$ The Court upheld both the Board's determination that the decision to subcontract was a mandatory subject of bargaining, and the Board's remedial order requiring cancellation of the subcontract.

The Court cautiously limits its decision to "the facts of this case."15 Although it does not make explicit what facts distinguish this case from other subcontracting cases, three elements are strongly emphasized. First, this was a subcontracting of work previously performed by bargaining unit employees, not the subcontracting of new work or the renewal of existing arrangements. It was unilateral action by the employer which decreased the number of jobs available. Second, the employer's decision to subcontract was an effort to economize on labor costs by reducing the number of maintenance employees needed, decreasing the fringe benefits, and eliminating overtime. Third, the work continued to be done on the employer's premises in the same general manner, but with the subcontractor's employees. This last factor is probably less relevant to the employer's duty to bargain than to the appropriateness of the remedy imposed by the Board.

The impact of this decision is not measured by its narrow holding that employers are required to bargain with the union before making such subcontracts. Far more important is the Court's projection of guidelines for determining the boundaries of compulsory bargaining. Mr. Justice Stewart, in his concurring opinion, helpfully demonstrates the inadequacy of the guides rejected by the Court. His search of the legislative history produces nothing more than a vague Congressional purpose to limit the subjects of bargaining in some undefined way. $\mathrm{He}$ is compelled to admit that the statutory words, "terms and conditions of employment" provide no workable guide, for they obviously encompass discharge, seniority, and compulsory retirement which "concern the very existence of employment," 16 but define no line separating other management decisions such as introduction of automated equipment, change of product, or refinancing which also affect job security. He is finally forced to take refuge in intuitive distinctions between "managerial decisions which lie at the core of managerial control, . . . which are fundamental to the direction of the enterprise," 17 and those decisions

14. Fibreboard Paper Products Corp., 138 N.L.R.B. 550 (1962), enforced 322 F.2d 411 (D.C. Cir. 1963).

15. 379 U.S. at 209.

16. Id. at 222 .

17. Id. at 223 . 
which are "in themselves primarily about conditions of employment." 18

Searching for something better than this visceral test, the majority looked to the underlying purpose of the duty to bargain. Bargaining is legally compelled because of the belief that industrial conflict can be reduced "by subjecting labor management controversies to the mediatory influence of negotiation." 19 From this premise flow two tests. First, is the subject of such vital concern to both labor and management that it is likely to lead to controversy and industrial conflict? Second, is collective bargaining appropriate for resolving such issues? In applying these tests the Court does not look inward to its own notion of what is of vital concern or what is appropriate for bargaining, but outward to industrial experience. Said the Court:

While not determinative, it is appropriate to look to industrial bargaining practices in appraising the propriety of including a particular subject within the scope of mandatory bargaining. Industrial experience is not only reflective of the interests of labor and management in the subject matter but is also indicative of the amenability of such subjects to the collective bargaining process. ${ }^{20}$

Subcontracting is a mandatory subject of bargaining because, "Experience illustrates that contracting out in one form or another has been brought, widely and successfully within the collective bargaining framework."21

The implications of this approach reach far beyond the problem of subcontracting, for it reads the words and purposes of the statute to fit an evolving system of collective bargaining. The legal duty to bargain is not frozen in legislative moulds cast for 1947 practices, but is constantly reshaped by changing practices. As substantial numbers of unions and employers voluntarily bring new subjects within the framework of collective negotiations, other unions and employers will be required to submit these matters to the negotiating process. The result will undoubtedly be to expand the area of mandatory bargaining, not because the Court prefers more inclusive bargaining, but because members of the industrial community expand the area of collective agreement. The standard is indeed flexible, not bending with judicial whims, but adapting to changing practices. ${ }^{22}$

18. Ibid.

19. Id. at 214 .

20. Id. at 211.

21. Ibid.

22. The standard is, of course, neither mechanical nor precise. Determining when a subject has become common enough in collective agreements to be considered as mandatory will require a measure of judgment on the part of the Board and the Court. Also, drawing fine distinctions, such as between various kinds of subcontracting arrangements, may not be possible by looking only to existing practices. 
In Fibreboard, the Court was confronted with an 18-year-old statutory provision which gave no explicit guidance. A workable standard had to be created. The Court's projected standard was expressive of the underlying policy of the provision; it gave continuing viability to the duty to bargain in a changing industrial society; and, most important, the Court avoided imposing its subjective judgment as to what matters are "at the core of managerial control" but looked to the objective judgment of unions and employers as evidenced by their collective agreements. A more constructive solution cannot be expected of the Court.

\section{Anti-Union Plant Closures-Discrimination at Darlington}

The Court's performance in the much publicized Darlington Mills ${ }^{23}$ case was of quite a different character, leaving in its wake disturbing doubts if not destruction. Darlington Manufacturing Company, which operated a single textile mill, was one of twenty-seven mills controlled by the Milliken family through Deering Milliken \& Company, a New York selling house. When the Textile Workers Union sought to organize Darlington and petitioned for a representation election, Darlington threatened to close the mill if the union won the election. The union won the election by a narrow margin and Darlington made good its threat, selling its plant and machinery piecemeal and liquidating the corporation.

The NLRB found that this closing was motivated not by economic considerations but solely by anti-union animus. The Board held that Darlington had thereby discriminatorily discharged its employees in violation of Section 8(a)(3). The Board further held, in the alternative, that since Darlington was a part of a single integrated employer group, Deering Milliken had, by closing part of its enterprise unlawfully discriminated against the employees. As a remedy the Board ordered back pay for all Darlington employees until they received substantially equivalent employment or were put on preferential hiring lists at other Deering Milliken mills. ${ }^{24}$

The Court confronted both alternatives posed by the Board's decision - first, that Darlington as a separate employer had violated the statute by going completely out of business without providing for its employees; and second, that Deering Milliken as a single enterprise had violated the statute by closing part of its business.

On the first alternative, the Court flatly rejected the contention that an employer can, by going out of business, commit an unfair labor

23. NLRB v. Darlington Manufacturing Co., 380 U.S. 263 (1965).

24. 139 N.L.R.B. 241 (1962), enforcement denied 325 F.2d 682 (4th Cir. 1963). 
practice, even though the "liquidation is motivated by vindictiveness towards the union." 25 The Court, as its premise and conclusion, declared:

A proposition that a single businessman cannot choose to go out of business if he wants to would represent such a startling innovation that it should not be entertained without the clearest manifestation of legislative intent or unequivocal judicial precedent so construing the Labor Relations Act. We find neither. ${ }^{26}$

We might wonder whether the Court has not grown suddenly and strangely timid to be so easily startled by innovations, were not its own conclusions so startling. For the Court has concluded that an employer can discharge his employees solely because they have voted for a union. The employer can thus not only punish his own employees in a way which they will long remember, but can also provide a vivid object lesson to all others who consider challenging their anti-union employers. This, under a statute which guarantees to workers the right to bargain through representatives of their own choosing, which prohibits employers from coercing employees in the free exercise of their rights, and which specifically bans "discrimination . . . in employment to . . . discourage membership in any labor organization." 27

One would have thought that the bare words of the statute would be a clear enough manifestation of legislative intent. But if the Court found that Congress has not spoken clearly, then the Court's own words in Radio Officers ${ }^{28}$ should have sufficed, for there the Court cut through the words of Section 8(a)(3) to declare:

The policy of the Act is to insulate employees' jobs from their organizational rights. Thus Sections $8(a)(3)$ and $8(b)(2)$ were designed to allow employees to freely exercise their right to join unions, be good, bad, or indifferent members ... without imperiling their livelihood. ${ }^{29}$

The rationale of the Court in Darlington Mills is nearly as startling as its conclusion. To the argument that the employer's closing his plant was similar to a discriminatory lockout or a runaway shop, the Court answered that, "One of the purposes of the ... Act is to prohibit the discriminatory use of economic weapons to obtain future benefits." 30

25. 380 U.S. at 274.

26. Id. at 270 .

27. 61 Stat. 140 (1947), 29 U.S.C. § 158 (1964).

28. Radio Officers' Union v. NLRB, 347 U.S. 17 (1954).

29. 347 U.S. at 40 .

30. 380 U.S. at 271-72. 
The discriminatory lockout and runaway shop discourage collective employee activities in the future. "But a complete liquidation of a business," said the Court, "yields no such future benefit for the employer." 31 We had always supposed that the purpose of the statute was affirmatively to protect employees in the exercise of their rights, not merely to preclude employers from profiting from destruction of those rights. Indeed, the dominant remedial principle, particularly in Section 8 (a) (3) violations, has always been to make the injured employees whole and not merely to deprive the employer of his ill-gotten gains. ${ }^{32}$

To reinforce its conclusion the Court suggests that the Board's rule was aimed at an unlikely evil-the possibility that employers will stand on principle and liquidate their businesses is "surely too remote to be considered [a danger] at which the labor statutes were aimed." 33 Apart from the question of what evidence or expertise the Court relies to make this judgment, this is to see no teeth in the bear's tail. For the right to close a business has at the other end the far more real danger-the right to warn employees in advance, just as Darlington did. The Court, in a footnote, denies that its decision would justify an employer "threatening" to close his plant, but acknowledges that he could "announce a decision to close already reached" 34 if the employees vote for the union. The employer determined to defeat unionization needs no more. He can make a "definite decision" prior to the election and trumpet it to the employees. If the employees take his threat seriously and vote against the union, the definitiveness of his decision can never be tested. If the employees gamble that he is bluffing and vote for the union, he can continue operations. Though the Board can find that his "decision" was a "threat" and an unfair labor practice, its cease and desist order will be painless. He can be ordered not to threaten again, but he will certainly not be ordered to fulfill his "decision." The employer thus runs no real risk while the union must ask the employees to play Russian roulette with their jobs. Permeating this part of the opinion is judicial tenderness toward "the employer's right to go out of business." The Court conjures up the vision of an employer being ordered to remain in business, ignoring that the Board had ordered only that employees be put on preferential hiring lists in other Deering Milliken plants. The question was not whether an employer could choose to go out of busi-

31. Id. at 272 .

32. See, for example, Republic Steel Corp. v. NLRB, 311 U.S. 7 (1940); Phelps Dodge Corp. v. NLRB, 313 U.S. 177 (1941).

33. 380 U.S. at 272.

34. Id. at $274, \mathrm{n} .20$. 
ness but whether, if he did so choose, he could be required to make whole employees whom he discriminatorily discharged.

The second branch of the Court's decision is even more baffling and disturbing. If Darlington was an integral part of the Deering Milliken enterprise, then there was only a partial closing. A discriminatory partial closing, said the Court, can be an unfair labor practice for it may discourage "the free exercise of Section 7 rights among remaining employees." ${ }^{35}$ To be an unfair labor practice, two elements must be present. In the Court's words,

a partial closing is an unfair labor practice under Section 8(a)(3) if motivated by a purpose to chill unionism in any of the remaining plants of the single employer and if the employer may reasonably have foreseen that such closing would likely have that effect. ${ }^{36}$

Because the Board's findings failed to establish the "vital requisites" of purpose and effect, the Court remanded the case for further findings. It did not suffice to argue that a partial closing for openly avowed discriminatory reasons necessarily had an adverse impact on unionization. A showing of motivation to achieve that effect is necessary, and explicit Board findings are necessary "in an area which trenches so closely upon otherwise legitimate employer prerogatives." 37

The Court's phrasing of the required findings is puzzling, but the core of the requirement is plain. It is not enough that Deering Milliken discharged part of its employees because they voted for the union. It is not enough that such discharge had the effect of intimidating the remaining employees. There must be an express finding that the motivation for discharging some is to intimidate the others. The Board may have little difficulty in making the necessary findings in this case, but only because of the employer's lack of finesse. If a multi-plant employer closes his only unionized plant but vigorously asserts to his other employees that the closure was solely for economic reasons, proof of the necessary purpose to intimidate the remaining employees may be extremely difficult. Indeed, such motivation may in fact be absent, for it is enough for the employer that he has escaped collective bargaining in the only plant where the employees chose to unionize. Similarly, if a runaway employer reopens in a non-union area under a new name, concealing from his new employees that he is a fugitive from collective bargaining, proof of either the purpose or the effect of intimidating his new employees will be impossible. He is content to be rid of the union

35. Id. at 275 .

36. Ibid.

37. Id. at 276 . 
for the time being, and if his new employees organize, he can make another quiet escape. This scarcely guarantees to employees the right to bargain through representatives of their own choosing.

The mischief in the Court's reasoning is that it ignores the rights of those who have been discriminatorily discharged. The essence of the Court's logic is that discharge for supporting the union is not itself an unfair labor practice, that it is no wrong as to the ones discharged, and that the law is not concerned with their injury. Discrimination against them is an evil only when it intimidates others; any remedy given them is only to make others feel secure. This is to see in the execution of hostages nothing more than an intimidation of the living; it is to make murder a crime only when the killer's purpose is to instill fear.

Explaining the Darlington decision is difficult for it is inherently incredible. The results do not square with the words and purposes of the statute; the rationale is without precedent in Board or court decisions; and though the Court purports to weigh the practical impact of its decision, it glosses over the real and obvious dangers. The right to go out of business without any responsibility to employees was treated as an absolute right, unqualified by the rights of employees created by the statute. There is no clue why this right is significantly different from the right to close part of the business, and Fibreboard suggests that this right is subordinate to statutory rights. In groping for explanations one is tempted to wonder whether if the Court's unarticulated if not subconscious concern was not with the right of the Heart of Atlanta Motel ${ }^{38}$ to go out of business under a somewhat parallel statute which prohibits discrimination. For again, labor law cases are a subordinate part of the Court's work and may be colored by the Court's preoccupying concerns.

\section{The EMPloyer's Economic Weapons-Lockouts and RePlacements}

The most important labor law cases of the last term, both from the standpoint of their impact on collective bargaining and in their implications for the lawmaking process, were the two Lockout Cases. Together, they significantly alter the relative economic strength of unions and employers in at least some collective bargaining relationships. More important to our larger purpose here, they reveal the role of Congress, the Board and the courts in regulating the economic weapons of the parties.

In American Ship Building Company v. $N L R B,,^{39}$ the employer was engaged in repairing ships on the Great Lakes, a highly seasonal busi-

38. Heart of Atlanta Motel, Inc. v. United States, 379 U.S. 184 (1964).

39. 380 U.S. 300 (1965). 
ness concentrated during the winter months when the lakes are frozen. When the collective agreement expired on August 1, and the parties were unable to reach an agreement, the union proposed a six-month extension-to expire at the height of the busy season. The Company objected to any extension which would make it more vulnerable to a strike, closed its yards and laid off all employees until the union agreed to a new two-year contract. The NLRB, following long established precedents, held that the lockout violated Sections $8(a)(1)$ and $8(a)(3)$, because the employer's purpose was not to avert any special economic losses but solely to bring economic pressure on the union to secure prompt settlement of the dispute on favorable terms. ${ }^{40}$

The Court rejected this analysis, saying that the Board "in essence denied the use of the bargaining lockout to the employer because of its conviction that this device would give the employer 'too much power." "41 The Board's previous position limiting single employer lockouts was wiped out with this declaration:

We hold that an employer violates neither $\S 8(a)(1)$ nor $\S 8(a)(3)$ when, after a bargaining impasse has been reached, he temporarily shuts down his plant and lays off his employees for the sole purpose of bringing economic pressure to bear in support of his legitimate bargaining position. ${ }^{42}$

The immediate impact of this decision is obvious-the union no longer has exclusive control over the timing of the economic battle. ${ }^{43}$ No longer need the employer hunker down, waiting for the union's attack when he is most vulnerable; he can take the initiative when he has maximum strength. This change can significantly alter the balance of bargaining power and the content of the bargain struck. ${ }^{44}$ The contract made at American Ship Building after a two-month lockout in August and September will not be the same as one made after a two month strike in January and February. The impact of the case will be

40. 142 N.L.R.B. 1362 (1963). The Board's order was enforced in NLRB v. American Ship Building Co., 331 F.2d 839 (D.C. Cir. 1964).

41. 380 U.S. at 317 .

42. Id. at 318 .

43. The union loses control not only over the beginning of the conflict but also over its ending. No longer can the employees insist on reinstatement by making an unconditional offer to return to work. The employer can continue the shut-down until the union has concluded a binding collective agreement.

44. Prior to this decision the employer could often find ways of provoking a strike at a time advantageous to him. He could do so, however, only by taking some drastic action which would anger his employees beyond the union's ability to restrain them. The employer thus could take the initiative only at the expense of bearing the onus of unfairness and solidifying the employees' antagonism. 
uneven; for while the timing of the economic contest may be of minor importance in many industries, it can be of critical importance in many others, ranging from automobile manufacturing to newspaper publishing. In these industries the employer now has a new economic weapon. Of course, the employer's control over the timing of the conflict is limited by the termination date of the collective agreement. But this restriction only means that there will be more bitter bargaining over this term, and in this bargaining, the employer's hand may now be strengthened by the lockout.

The Court's legalization of the lockout as an instrument of economic pressure inevitably raises the question whether the employer, before locking out, must bargain to impasse with the union. American Ship Building had bargained to impasse, and the Court consistently included this element in stating its holding. But there is no other clue in its language or logic. The unanswered question leads us to look to other forms of economic force and to whether their use is conditioned on first bargaining to impasse. Unfortunately, this investigation brings us face to face with a larger ambiguity. Another form in which an employer can take the initiative in exercising force in bargaining is unilaterally to change the terms and conditions of employment. It is firmly settled that before he takes this step he must bargain to impasse. ${ }^{45}$ On the other hand, it is commonly assumed that a union can resort to economic force in the form of a strike without bargaining to impasse. At this point one might be tempted to consider whether a lockout should be viewed as a form of employer initiative, like a unilateral change, or as the counterpart of the strike. ${ }^{46}$ Such a pursuit of analogies, however, can only carry us further from the central consideration.

The function of the statutory duty to bargain, the Court has underlined in Fibreboard, is to promote the peaceful settlement of industrial disputes by subjecting them to the mediatory influence of negotiation. This view proceeds from the premise that full discussion can often dispel misunderstanding, change fixed positions or discover bases for agreement, thereby preventing industrial conflict. The purpose of the duty to bargain, so conceived, can be fulfilled only by requiring exhaustion of discussion before resort to economic force. The premise of Fibreboard thus points to the conclusion that the employer cannot

45. See NLRB v. Katz, 369 U.S. 736 (1962); NLRB v. Crompton-Highland Mills, 337 U.S. 217 (1949).

46. The Court carefully avoided equating the lockout with the strike. "The correlative use of the words in the statute," said the Court, showed only "that lockouts will be used in the bargaining process in some fashion." 380 U.S. at 315 . 
lockout until he has bargained to impasse. If the Court arrives at this conclusion, can it stop there? Does not the same policy require that the union also exhaust discussion before resorting to economic force? The only justification for allowing the union to strike without first bargaining to impasse is to give it the widest freedom in timing the strike. But such a claim will ring hollow in a court which has declared that "there is nothing in the statute which would imply that the right to strike 'carries with it' the right exclusively to determine the timing and duration of all work stoppages." ${ }^{\prime 4}$ Indeed, the Court has hinted in previous cases that for the union to strike first and talk later might constitute a violation of the duty to bargain in good faith. ${ }^{48}$

The practical impact of American Ship Building on the relative economic strength of the parties cannot be measured without knowing whether, and under what conditions, an employer who has locked out his employees can hire replacements to do their work. The companion case, $N L R B$ v. Brown, ${ }^{49}$ gives only a partial answer. The union, after failing to reach an agreement with an employer group of six retail food stores, struck one of them. The other five immediately locked out all employees represented by the union, and all six continued to carry on business with the aid of temporary replacements. When a collective agreement was signed, the employers released the replacements and reinstated all strikers and locked out employees. The Board held that under Buffalo Linen, ${ }^{50}$ the employers were entitled to lockout to preserve the multiple employer unit from disintegration by the union's whipsaw strike, but that hiring replacements for locked out employees constituted a violation of Sections $8(a)(1)$ and $8(a)(3) .{ }^{51}$

The Court, however, was unable to "see how the continued operations of the respondents and their use of temporary replacements ... are inherently more destructive of employees rights than is the lockout itself." ${ }^{52}$ Both were part of a defensive measure to preserve the multipleemployer group in the face of a whipsaw strike. Since the struck employer could, under Mackay Radio, ${ }^{53}$ use replacements to remain open, the other employers must also be entitled to do so or they would be

47. Id. at 310 .

48. See NLRB v. Insurance Agents Union, 361 U.S. 477 (1960) n.15. In NLRB v. Washington Aluminum Co., 370 U.S. 9 (1962) the Court inferentially suggests that if employees who have a grievance walk out without first making known their grievance to management, their strike might not be a protected activity.

49. 380 U.S. 278 (1965).

50. NLRB v. Local 449, Int'l Bhd. of Teamsters, 353 U.S. 87 (1957).

51. 137 N.L.R.B 73 (1962), enforcement denied, 319 F.2d 7 (10th Cir. 1963).

52. 380 U.S. at 284.

53. NLRB v. Mackay Radio \& Telegraph Co., 304 U.S. 333 (1938). 
placed at a competitive disadvantage and become the victims of the union's whipsaw. The employers' action "was a measure reasonably adapted to the achievement of a legitimate end-preserving the integrity of the multiple employer bargaining unit." 54

The Court need have said no more. It could have cautiously limited its logic to applying existing rules on replacements-that where the union took the initiative and struck one member of an employer group, the others could treat the whipsaw as a strike directed against all of them and use the normal defensive measure of hiring replacements. Brown might, therefore, have been only a special application of the Mackay rule. The Court's plunging into the new problems posed by its holding in American Ship Building that the employer might take the initiative could have been postponed until the Board had an opportunity to study the problems and evolve solutions in concrete cases.

However, the Court felt compelled to reach out for a broader formulation applicable to all lockouts:

When the resulting harm to employee rights is thus comparatively slight, and a substantial and legitimate business end is served, the employers' conduct is prima facie lawful. ${ }^{55}$

Or more directly, in the absence of anti-union motivations, the legality of hiring replacements depends on a balancing of these conflicting interests. This broader formulation, however, adds little light; rather, it all but blows the candle out. Are the weights altered when the employer initiates the shutdown, as in American Ship Building? Does the hiring of replacements then result in greater "harm to employee rights," and does the employer's preventive action make replacements serve any less "a substantial and legitimate business end?" Is the balance tipped because the replacements are permanent rather than temporary? The economic impact on the employee is more severe, is this a greater harm to his "rights"? And does the employer's difficulty in obtaining temporary employees and his disruption in dismissing them mean that permanent replacements serve a more "substantial and legitimate business end." Indeed, the Court's formulation fails even to explain Brown itself. When an employee who offers to continue working on his employer's terms is temporarily replaced solely because he is represented by the union, why is the injury to his rights "comparatively slight"? And when integrity of the bargaining unit could be preserved by the five employers who locked out insisting that the one struck also close, why

54. 380 U.S. at 289.

55. Ibid. 
does their all staying open serve a substantial business end? We know it is so only because the Court says it is so. And when we try to analyze the balancing process we begin to sense that we do not even know what interests are to be placed in the scales.

The conflicting interests to be weighed begin to emerge in American Ship Building where the Court used the same balancing approach in upholding the lockout. Quoting from Erie Resistor, ${ }^{56}$ the Court said that determining the legality of the employer's economic measures entails the-

delicate task ... of weighing the interests of employees in concerted activity against the interest of the employer in operating his business in a particular manner. ${ }^{57}$

In the context of an economic strike or a bargaining lockout the interests of the employees is to use economic force to make their bargaining demands effective. The employer's interest is likewise to use economic force to resist the union's demands and to run the business on terms acceptable to him. The interest of each is to muster an arsenal of economic weapons sufficient to overcome its opponent. In each case the weighing process is one of parcelling out those weapons to the opposing parties. Mackay Radio gave to the employer the weapon of permanent replacements to counteract the union's weapon of the strike; Buffalo Linen gave to multiple employer groups the right to lockout to defend against the too effective whipsaw strike; and Erie Resistor refused to allow the employer to lengthen his replacement weapon by adding twenty years superseniority.

Despite its disarming formulation, what the Court is balancing is not legal rights but economic weapons. In American Ship Building the Court is simply asserting that in its judgment the employer should not be denied the strategic advantage of picking the time of battle; and in Brown the Court concludes that to defend against a whipsaw strike, the employer needs to have the added weapon of hiring temporary replacements. Another year the Court will declare what other combinations of weapons are needed, and will then patiently, if unhelpfully, explain that balancing of the interests requires the result.

Once we see clearly that the problem in the Lockout Cases is one of allocating weapons, we can confront the question of how that allocation is to be made. Certainly, the legal status of economic weapons does not depend on logic. The elaborate rationalizations of the Court are cal-

56. NLRB v. Erie Resistor Corp., 373 U.S. 221 (1963).

57. American Ship Building Co. v. Labor Board, 380 U.S. 312 (1964). 
culated to confuse everyone, including the Justices. Not even the venerable Mackay Radio rule has any inherent logic. Quite the contrary. In logical terms, for the employer to hire replacements is a form of individual bargaining and a denial of the union's statutory status as exclusive representative. For the employer to retain permanent replacements after the strike is to give preference to those who do not strikelogically a form of discrimination. Logic and the words of the statute would have led to the conclusion that when the majority union struck, the employer could not operate until he reached an agreement with the representative of his employees. The right to hire permanent replacements for strikers was based simply on the Board's practical judgment that employers should be allowed this countermeasure to the strike. Neither Buffalo Linen nor Erie Resistor have any more compelling logic. The Board looked to the relative effectiveness of the parties' economic weapons and defined their legality to prevent what it judged would create an imbalance of power. In each case the Court accepted the Board's judgment.

The legality of economic weapons depends purely on pragmatic considerations, and the primary consideration has been achieving a rough equality of bargaining power. In arguing American Ship Building the Board candidly acknowledged that its decision was based on its expert judgment that availability of the lockout "would so substantially tip the scales in the employer's favor as to defeat the Congressional purpose of placing employers on a par with their adversaries at the bargaining table." 58

Such a frank confrontation of the problem was more than the Court could bear. Dusting off the birch rod of Insurance Agents, ${ }^{59}$ the Court accused the Board of "functioning as an arbiter of the sort of economic weapons the parties can use in seeking to gain acceptance of their bargaining demands," 60 and twice delivered the stinging rebuke that this was "the unauthorized assumption by an agency of major policy decisions which are properly made by Congress." ${ }_{11}$ The Court then substituted itself as the arbiter, invoked its balancing test, and decided the sort of economic weapons the parties could use.

This is the most troublesome aspect of the Lockout Cases-the Court's refusal to confront the raw issue which must be decided, and its driving into the darkness of lightless language the actual grounds for its

58. Ibid.

59. NLRB v. Insurance Agents Union, 361 U.S. 477 (1960).

60. 361 U.S. at 312 .

61. Id. at 318 . 
decision. Of course, the statute does not give the Board "general authority to assess the relative economic power of the adversaries in the bargaining process." 62 Of course, determining the weapons the party can use is a "major policy decision . . . properly made by Congress." 63 Of course, where Congress has given guides the Board-and the Courts - should follow. But Congress often gives no guides. The statute defines at least some of the limits on unions' economic weapons, leaving the Board and the Court to improvise the rest. But as the statute says nearly nothing about employers' economic weapons in bargaining disputes; the allocation has been made by fiat of Board and Court. The fact that these are major policy decisions does not free the Board or the Court from deciding, nor does it dictate their decisions. It does mean, however, that sensible decisions cannot be made by denying that they necessarily involve problems of policy. We cannot usefully discuss whether the Lockout Cases were sensibly decided, or how their offspring should be decided, until we get an exploration of the relevant economic facts and social values. ${ }^{64}$ And this difficult task is not even begun.

\section{Collective Bargaining and the Anti-Trust Laws - Mine Workers and Meat Cutters}

The long and tortuous path of the anti-trust laws' application to labor unions and collective bargaining took two sudden turns in the Supreme Court last term. For over forty years the courts used the Sherman Act as an instrument for curbing union activities. The ambiguous provisions of the Clayton Act served only to bind the chains tighter by adding the injunction remedy. ${ }^{65}$ Finally, in 1941, Mr. Justice Frankfurter discovered a key in the Norris-LaGuardia Act and in United States $v$. Hutcheson ${ }^{66}$ freed unions from the shackles of the anti-trust laws. That is, all but one shackle- "so long as the union acts in self interest and

62. Id. at 317 .

63. Id. at 318 .

64. Even casual examination reveals major flaws in the "balancing of bargaining power" approach. What constitutes a proper balance depends largely upon the personal predelictions of the balancer. Even apart from this, the relative strength of unions and employers is not the same in all industries or regions, and may change with the business cycle and level of unemployment. We do not know whether the lockout would strengthen employers who are relatively weak or relatively strong. The same is true of the hiring of replacements. Full inquiry might lead to full scepticism of any test. But that itself may be a guide. For when dealing with a going collective bargaining system, there is a significant value in keeping the rules unchanged and not upsetting an existing equilibrium. If the Court (or the Board) does not know whether or not its decision will help, then perhaps it should leave the existing arbitrary rules be.

65. 38 Stat. 737 (1914), 15 U.S.C. \& 27 (1958).

66. 312 U.S. 219 (1941). 
does not combine with non-labor groups."67 This exception was applied four years later in Allen-Bradley ${ }^{68}$ where the Electrical Workers had combined with electrical contractors and manufacturers to rig the New York market and exclude all outside competition. For twenty years the reach of this case was debated but the Court kept its silence. Now the Court has spoken twice and pushed the law down two unexplored paths.

In United Mine Workers $v$. Pennington, ${ }^{69}$ the union was sued by a small mine company for having conspired with an association of large mine companies to drive the small mines out of business. The jury found there was a conspiracy and awarded treble damages of $\$ 270,000$. The core of the conspiracy was a collective bargaining agreement between the union and the larger operators first made in 1950 to eliminate overproduction and bring stability to the industry. The union agreed not to resist mechanization, and the employers agreed to increase wages as productivity increased. The union further agreed that it would impose the same wage terms on all of the small mine operators, even though they were unable to mechanize and therefore unable to pay the wages. By closing the small mines, overproduction would be avoided. The union and the large operators took other steps to prevent the small mines from escaping by operating non-union. The large operators agreed not to lease coal lands to non-union operators and not to sell or buy coal from such companies. The parties cooperated in obtaining Walsh-Healy wage orders incorporating the union wages and in inducing TVA to change its purchasing program to foreclose purchases from the small mines. In addition, four of the larger companies waged a destructive and collusive price-cutting campaign aimed at the small nonunion mines. Two of these companies were ones in which the union had large investments and over which it could exercise control.

Passing quickly over other elements of the conspiracy, the Court centered its attention on the provision in the collective agreement that the union would impose on other operators the same wages regardless of the employer's mechanization or ability to pay..$^{70}$ It was this provision which the Court found subjected the union to the anti-trust laws. Said the Court,

67. Id. at 232 .

68. Allen Bradley Co. v. Local 3, I.B.E.W., 325 U.S. 797 (1945).

69. 381 U.S. 657 (1965).

70. The opinion of the Court was delivered by Mr. Justice White and discussion is focused on that opinion. It represents a kind of middle ground between the concurring opinion of Mr. Justice Douglas, with whom Mr. Justice Black and Mr. Justice Clark agreed and the dissenting opinion of Mr. Justice Goldberg with whom Mr. Justice Harlan and Mr. Justice Stewart agreed. 
[W] think a union forfeits its exemption from the anti-trust laws when it is clearly shown that it has agreed with one set of employers to impose a certain wage scale on other bargaining units..$^{71}$

The Court made clear that the union could make a wage agreement with a multiple employer bargaining unit. Also, the union could, as a matter of its own policy, seek to standardize wages among employers or to allow differentials because of the employer's competitive position. What the union could not do was agree with the employers in one bargaining unit to seek particular terms from employers in another bargaining unit. Such an agreement was bad "without regard to predatory intention or effect in the particular case." 72 The vice in the agreement is that "the union surrenders its freedom of action with respect to its bargaining policy" and its interest becomes bound to that of the employer. ${ }^{73}$ "It is just such restraints upon freedom of action to act according to their own choice and discretion," said the Court, "that run counter to anti-trust policy." 74

The repercussions of this decision will be felt immediately in the content of collective agreements, for the parties must hasten to excise such clauses and prayerfully count the days until the limitation period on treble damage actions runs. A wide range of clauses, variously worded but having the same restraining effect, may fall within the compass of the prohibition. For example, a "most favored nation" clause does not directly require the union to bargain for the same terms, but failure to do so has such grievous consequences that the union has effectively surrendered its freedom of action as to its bargaining policy. The anti-trust laws are seldom distracted from substance by form.

The repercussions reach beyond the agreement to the bargaining process. No more can an employer before signing an agreement ask the union for assurances that it will go to his competitors and do likewise, nor can the union as an inducement promise to do so. The employer might ask the union whether its bargaining policy was to standardize wages and the union might say that it was. Though in form no violation, this exchange might appear to a jury to be an implied understanding. Thus an important matter of mutual concern can be brought to the bargaining table only at the risk of a treble damage action.

The impact of the case may be to inhibit unions from enforcing

71. 381 U.S. at 665, n.2.

72. Id. at 668 .

73. Ibid.

74. Ibid. 
standardized wage policies in spite of the Court's efforts to allay such fears. The Court explicitly states that the union acting unilaterally can vigorously implement such a policy even though it knows that some employers cannot compete. It further states that, "such union conduct is not alone sufficient evidence. . . . There must be additional direct or indirect evidence of the conspiracy."75 But a prudent union might well fear the findings of a jury when suit is brought by an employer driven out of business by the union's demands.

The second case before the Court was another cup of tea. ${ }^{76}$ The Meat Cutters Union negotiated with an employers' association of independent meat retailers for a provision which limited market operating hours to 9 a.m. to 6 p.m. Jewel Tea objected to this provision because it would prevent the sale of pre-packaged meat on a self-service basis in its supermarkets during evening hours. Under the duress of a strike vote, Jewel signed and then sued the union for damages under the anti-trust laws. After a trial without a jury the judge dismissed the case. He found no evidence of an agreement between the union and the employers' association to force the restrictive marketing hours on Jewel, and concluded that the union acted unilaterally to enforce its own bargaining policy. He further found that the union, in limiting the hours of sale, was seeking to protect working standards, for if meat counters were open, the butchers would be required either to do night work or to leave their work to be done by others unskilled in the trade. ${ }^{77}$

The lower court's findings that there was no agreement between the union and the association to impose the marketing hours restriction on Jewel precluded any violation under $U M W$ v. Pennington. This, however, did not end the inquiry. ${ }^{78}$ The mere fact that the collective agreement was between a single employer and a single union representing its employees does not mean, said Mr. Justice White, that the agreement is immune from attack under the anti-trust laws. If, for example, the union had demanded that Jewel maintain a certain schedule of prices and Jewel had agreed, there would be serious doubt, whether

75. 381 U.S. at $665, \mathrm{n} .2$.

76. Local 189, Amalgamated Meat Cutters, AFL-CIO v. Jewel Tea Co., 380 U.S. 676 (1965).

77. Jewel Tea Co. v. Amalgamated Meat Cutters, 215 F. Supp. 837 (1963), reversed, 331 F.2d 547 (7th Cir. 1964).

78. On the underlying issues the division of the Court in this case was the same as in $U M W$ v. Pennington. See note 70 supra. Here, Mr. Justice Douglas' opinion is a dissent and Mr. Justice Goldberg's opinion is a concurrence. Again, discussion is focused on $\mathrm{Mr}$. Justice White's opinion. Because the three Justices joining in the Goldberg opinion concur only in the judgment, there is no opinion of the Court in this case. 
either the union or Jewel could claim immunity by reason of the labor exemption. The immunity extends only to those matters which are "intimately related to wages, hours and working conditions." 79 In view of the trial judge's findings that night operations were not feasible without having either butchers or other employees present to service the meat counters, the marketing hours provision was "a subject of immediate and legitimate concern to union members," 80 and was immune from attack.

Although the union escaped liability, collective agreements were made captives of the anti-trust laws. Even a simple agreement between a union and an employer loses its immunity if it regulates matters not "intimately related to wages, hours and working conditions." 81 Although the location of the line is left in doubt, it is generally the same line as that separating mandatory and non-mandatory subjects of bargaining. Thus, any agreement on a non-mandatory subject may lose its claim to immunity, and if then found to be an unreasonable restraint on competition, will constitute a violation of the anti-trust laws. ${ }^{82}$

The most troublesome aspect of this decision is that the question whether the particular subject is "intimately related" to terms and conditions of employment will be decided in the District Court and often by a jury. The Court suggested that if self-service markets could operate without butchers after 6 p.m., then the marketing hours limitation might be viewed as nothing but an effort by the union to protect one group of employers from competition by another. The likelihood that a jury would so find is not remote. Many other provisions which could come within the broad reaches of mandatory bargaining may be seen by juries or district judges as having no purpose other than to protect against competition. Appellate review of such decisions, embedded as they are in subsidiary factual determinations, provides small safeguard.

Any understanding of why the Court reached these decisions must begin with the troubling question which was at the core of the Mine Workers case-why should a union's agreement to enforce a standardized wage cause the union to forfeit its exemption from the anti-trust laws? As Mr. Justice Goldberg reminds us in his dissenting opinion, one of the values of competition is to reward the most efficient producer

79. 381 U.S. at 689 .

80. Id. at 692 .

81. Id. at 689 .

82. The Court here bleeds some of the vitality from Fibreboard, for unions and employers may now be reluctant to bargain concerning non-mandatory subjects and thus not develop many practices which will permit growth in the scope of collective bargaining. 
and this objective is not achieved when employers compete on the basis of who pays the lowest wages. One of the functions of collective bargaining, as conceived and practiced in this country, is the elimination of price competition based on differences in labor standards. The national labor policy affirmatively promoted by the National Labor Relations Act endorses this focusing of competition on factors other than labor standards. An agreement to enforce standardized wages would therefore seem to fulfill, not to frustrate the purposes of both the labor acts and the anti-trust laws.

Both of the cases before the Court, however, made plain two rudimentary economic facts. First, the union's bargaining practices significantly affect the relative positions of competitors in the product market. By changing its bargaining practices, the union can change those relative positions, just as the Mine Workers change in 1950 made it difficult for small mines to compete. If the union allows differentials between employers, the size of those differentials can decide who will survive and who will perish. Second, uniform labor standards may disguise unequal treatment because of differences in employers' methods of operations. The Meat Cutters, by standardizing closing hours, could curb competition of supermarkets with independent retailers. The Miners, with a standardized wage scale, could aid either mechanized or non-mechanized mines, depending on whether that scale was high or low. The Court could not fail to see the impossibility of drawing a line between agreements to enforce standardized terms and agreements to enforce differentials.

The evil which the Court saw potential in the two cases before it is that one group of employers will enlist the bargaining power of the union to drive competitors out of business. Concessions would be granted to the union on the condition that it force on competitors terms which would make them unable to compete. The danger, as both cases warned, is as great when the terms are uniform in form as when they are baldly discriminatory.

The Mine Workers decision, however, gave only partial protection from this anti-competitive potential of collective bargaining, for it barred only the union's acting at the behest of an employer. But the Meat Cutters did not need to be told, much less urged, by the employers' association that to protect butcher's jobs in small stores it should impose closing hours on self-service in supermarkets. And the Mine Workers might well have unilaterally determined that higher wages for fewer members was preferable to preserving jobs in mines which could not pay more. Restrictions on bargaining policies of unions, however, 
would cut too deeply into the policy of the Labor Relations Acts. The Court felt compelled to limit its protection to agreements which sought to "prescribe labor standards outside the bargaining unit"83 -agreements which themselves conflicted with the policies of the Labor Relations Acts.

The Meat Cutters decision was an effort to partially close the door left open in Mine Workers. A union acting unilaterally lost its exemption from the anti-trust laws when it sought terms not intimately related to wages, hours and working conditions. The terms and conditions of employment bargained by the union may have an anti-competitive effect and are susceptible to manipulation for anti-competitive purposes, just as are matters not related to employment. But again, the policy of the Labor Acts counsels the Court against restricting the union's freedom to bargain so long as it stays within the range of subjects appropriate for bargaining under those Acts.

The end result is that these decisions reach only fragments of the anti-competitive potential which the Court saw in certain bargaining policies and practices. This meagre result is achieved at a cost of subjecting collective agreements and bargaining negotiations to the scrutiny of district judges and juries for hidden agreements and improper purposes. The history of the anti-trust warns of the dangers involved in opening courts to inquiries of this nature in labor matters.

The Court had another alternative-to follow the central thrust of United States $v$. Hutcheson, ${ }^{84}$ that the anti-trust laws are wholly unsuited for the regulation of labor relations. From Danbury Hatters ${ }^{85}$ to Allen Bradley ${ }^{86}$ the Court tried to develop rules or principles to relate the anti-trust laws to union activities and collective bargaining, but every effort failed. ${ }^{87}$ No principle proved adequate, and every rule disintegrated into unworkable distinctions. ${ }^{88}$ The Court was reluctant

83. 381 U.S. at 668 .

84. 312 U.S. 219 (1940).

85. Loewe v. Lawlor, 208 U.S. 274 (1908).

86. Allen Bradley Co. v. Local 3, I.B.E.W., 325 U.S. 797 (1945).

87. For a devastating analysis of the Court's decisions and its failure to reconcile the conflict between free competition and collective bargaining, $\rightarrow$ Winter, Collective Bargaining and Competition: The Application of Anti-Trust Statutes to Union Activities, 73 YaLE L.J. 14 (1963).

88. The failure stems not from the fault of the Court, but from the impossibility of the task. Two of the most thoughtful and perceptive students of the problem have arrived at essentially the same conclusion-reconciliation of the two policies is impossible and efforts to regulate labor under the anti-trust laws is hopeless or dangerous. See

$\rightarrow$ Winter, supra note $\rightarrow$ Meltzer, Labor Unions, Collective Bargaining and the Anti-Trust Laws, 32 U. of CHI. L. Rev. 659 (1965). 
to quit the field and leave it unregulated, but the reasons for that reluctance are now gone. Since Allen Bradley the National Labor Relations Act has been twice amended, and those amendments regulate the kinds of economic activities which had been the principal objects of attack in the labor cases involving the anti-trust laws-secondary boycotts, jurisdictional disputes, and hot-cargo clauses. ${ }^{89}$ The Court could now withdraw, for at least the strategic areas of the field has been occupied by Congress.

The opinions in both Mine Workers and Meat Cutters betray that the Court is dealing with problems well within the reach of the $\mathrm{Na}$ tional Labor Relations Act. The Court's test of the legality of the collective agreement is controlled by that Act; indeed, the kinds of conduct which the Court finds violative of the anti-trust laws involve unfair labor practices. Thus, for employers like the large mine operators to insist that as a condition of making a collective agreement the union promise to enforce the same terms on others would clearly be a refusal to bargain in good faith. ${ }^{90}$ For a union to agree, as the Mine Workers did, to refuse to consider any variation in negotiating with a small mine operator would seem to require a fixedness of position inconsistent with its duty to bargain. For a union like the Meat Cutters to insist on market closing hours when this was not related to terms and conditions of employment would likewise be a refusal to bargain. ${ }^{91}$ In short, the employers in these cases who claimed they were injured by the union's bargaining practices would have had potential remedies before the NLRB. The Court need not have allowed them, under the guise of the anti-trust laws, to litigate essentially the same issues in the district court and before a jury.

The Court could have used the two cases before it to withdraw from the impossible judicial task of regulating collective bargaining under the anti-trust laws. Nothing in the cases suggested that regulation under the Labor Acts was inadequate. As Mr. Justice Goldberg pointed out, the devices used by the Mine Workers bristled with potential unfair labor practices. And the very collective agreements attacked were the product and producers of potential unfair labor practices. The Court could have declared that the regulation of collective bargaining was

89. The chief exception was Coronado Coal Co. v. United Mine Workers of America, 268 U.S. 295 (1925), which the Court now seems to repudiate, for the core of the union's conduct in that case was the union's unilateral enforcement of its own policy of standardizing labor standards.

90. American Range Lines Inc., 13 N.L.R.B. 139 (1939); Newton Chevrolet, Inc., 37 N.L.R.B. 334 (1941).

91. NLRB v. Wooster Division of Borg-Warner Corp., 356 U.S. 342 (1958). 
solely for the provisions and procedures of the Labor Acts. If those Acts prove inadequate, Congress is always available to make new laws. Perhaps it can do better than the Court-it is not likely to do worse.

\section{The Court, Congress and the Board-Who's in Charge Here?}

The narrow focus on individual cases and their substantive impact pushes into the blurred background the roles being played by the Court, the Congress and the NLRB in evolving our labor law, and through it our national labor policy. But the process through which our labor law is made raises the more pervasive problems, for not only does the process affect the substance but it raises disturbing doubts as to the adequacy of existing legal institutions. The cases during the past year lay bare three characteristics of our lawmaking process.

First, the Court is confronted with cases which require it to decide controversial issues cutting near the core of national labor policy. In Fibreboard the Court had to decide what decisions in the operating of a business should be brought within the framework of collective bargaining and therefore within the reach of union influence by economic pressure. The scope of management prerogatives is not only one of the bitterest issues at the bargaining table; in its legal form it involves basic issues of public policy. The line between mandatory and non-mandatory subjects of bargaining defines not only the matters which management must discuss, but also the purposes for which a union can strike. It determines those business decisions which shall be subject to shared control and resolved by economic contest between union and employer. The determination of which subjects are within the framework of collective bargaining is but a step removed from the determination of whether or not there shall be collective bargaining at all.

In the Lockout Cases the Court had to decide what instruments of economic pressure should be available to each party. The instruments involved-the lockout and replacements-were not minor but major devices which could in many situations determine the balance of bargaining power and ultimately influence the content of the collective agreement. As the Court said in a different context, determining their legality was a "major policy decision properly made by Congress." 92 The Anti-Trust Cases required the Court to accommodate collective bargaining and free competition; to determine the balance between two major national policies. And it confronted that question at the most sensitive spot-the regulation of labor standards through collective agreements as a factor controlling competition in the product market.

92. American Ship Building Co. v. NLRB, 380 U.S. 300, 318 (1965). 
Second, the Court is compelled to make these substantial policy decisions with little or no guidance from Congress. Mr. Justice Stewart's recitation of statutory history in Fibreboard underlines that Congress did not, either by word or intent, mark the boundaries of bargainable subjects. On the contrary, it deliberately refused either to mark the boundaries or to say there were none. In 1947, the House bill explicitly limited bargaining to a detailed list of subjects, but the Conference Committee substituted the elastic terms "wages, hours and other terms and conditions of employment." No clue was given how far these could stretch, but only a vague assurance that there were some limits. Congress has been even more tight-lipped on the legality of the lockout. Despite awareness of the problem, Taft-Hartley contained only tantalizingly ambiguous references. ${ }^{93}$ For eighteen years successive Boards and Courts of Appeal have battled over the proper balance to be struck in allowing lockouts. ${ }^{94}$ Once before, in Buffalo Linen, ${ }^{95}$ the Supreme Court was required to act as final arbiter. Throughout this heated controversy, Congress maintained a stony silence, defaulting to the Court the responsibility for making this "major policy decision."

The failure or refusal of Congress to make hard policy decisions is exemplified in the history of the anti-trust laws. In 1890, the application of anti-trust restrictions to unions was hotly debated in the Senate, but the statute when passed was conspicuously silent. ${ }^{96}$ As the courts began to erect a legal structure on this sandy foundation of the absence of intent, perennial proposals were made to specifically exempt unions, but all of these died in committee. ${ }^{97}$ In 1914, after extended and bitter debate over immunizing unions from attack under the anti-trust laws, Congress wrote Sections 6 and 20 into the Clayton Act. ${ }^{98}$ But both committee reports and debates contained directly contradictory declarations of what these sections would do. In the words of Professor

93. In Sections $8(\mathrm{~d}), 203(\mathrm{c}), 206$, and 208(a), the terms "strike or lockout" were linked, but in all of these sections the concern was with preventing disruptions of production, not with defining the legality of particular economic weapons. 61 Stat. 142, 154, 155 (1947), 29 U.S.C. $\S \S 158,173,176,178$ (1958).

94. For descriptions of this continuing battle, see Koretz, Legality of the Lockout, 4 Syracuse L. Rev. 251 (1953); Koretz, The Lockout Revisited, 7 Syracuse L. Rev. 263 $(195 \rightarrow$ Meltzer, Single Employer and Multi-Employer Lockouts under the Taft-Hartley Act, 24 U. CHI. L. Rev. $70(195 \rightarrow$ Meltzer, Lockouts under the Labor Management Relations Acts: New Shadows on an Old Terrain, 28 U. CHI. L. REv. 614 (1961).

95. 353 U.S. 87 (1957).

96. For recounting of the history and the opposite inferences to be drawn, see Bowman, Labor and the Sherman Act (1930) p. 35-41, and Mason, Organized Labor and THE LAW (1925) p. 119-31.

97. See Frankfurter \& Greene, The Labor InJunction (1930) pp. 139-41.

98. 38 Stat. 731,738 (1914), 15 U.S.C. $\S 17,29$ U.S.C. § 52 (1958). 
Frankfurter, "The debates in Congress looked both ways .... The Supreme Court had to find meaning where Congress had done its best to conceal meaning." 99 Senator Norris cautiously avoided touching this issue in drafting the Norris-La Guardia Act ${ }^{100}$ and Professor Frankfurter in his hard-backed brief for the Act insisted that it gave immunity only from equitable as distinguished from legal remedies- "hitherto unlawful conduct remains unlawful." 101 Silence continued when Congress passed the Wagner Act with no indication that it was aware of the need to reconcile the policy of encouraging collective bargaining with that of protecting competition. United States $v$. Hutcheson turned the issue upside down, but Congress still said nothing. The Hartley Bill passed by the House in 1947 would have removed the exemption of unions created by that case, but the Conference Committee preferred silence. ${ }^{102}$ The debate has continued; proposals are regularly introduced into Congress to define the relation between union activities, collective bargaining, and the anti-trust laws, but Congress still refuses to speak. For seventy-five years Congress has shifted to the Court the responsibility for making the basic decisions of policy. This is a delegation of lawmaking without standards, for Congress has failed to find or to agree upon any guiding principles. The Mine Workers and Meat Cutters cases serve to underline that it is because of the default of Congress that the Court is in charge.

Third, the Court, confronted with difficult and delicate issues which it must resolve without guidance from Congress, does not rely upon the National Labor Relations Board for enlightenment or counsel. In its opinions during the last term the Court has plainly displayed a marked lack of confidence in the Board. Although the Court enforced the Board's order in Fibreboard, it attributed no weight to the Board's judgment and did not even invoke the Board's expertise to reinforce its own controversial decision. Later, in Meat Cutters the Court genuflected before the Board's expertise in determining bargainable subjects, and then made the determination for itself. In Darlington, the Court completely discarded the Board's judgment as to the impact of actual or threatened discriminatory plant closures by asserting that the proba-

99. Op. cit. supra n.97, at 143 and 145 .

100. Senator Norris deliberately refused to include provisions recommended by Professor Frankfurter and others which would have exempted unions from the anti-trust laws. See Kadish, Labor and the Law in Frankfurter: THE JUdGe (Mendelsohn, editor, 1964) p. 171-2.

101. Op. cit. supra n.97, at 215.

102. See H. Conf. Rep. No. 510, H.R. 3020, 80th Cong., 1st Sess. 65 (1947); 1 NLRB Leg. Hist. of Lab. Manag. Rel. Act 569 (1947). 
bilities of employers closing "are surely too remote to be considered dangers at which labor statutes aimed"; ${ }^{103}$ and further asserted that the danger of employers using threats was not of "sufficient significance" to justify restricting their prerogatives. Finally, in the Lockout Cases the Court bluntly repudiated any reliance on the Board. The Court not only substituted its own judgment in the particular case, but also declared:

Of course, due deference is to be rendered to agency determinations of fact, so long as there is substantial evidence to be found in the record as a whole. But where, as here, the review is not of a question of fact, but of a judgment as to the proper balance to be struck between conflicting interests, "the deference owed to an expert tribunal cannot be allowed to slip into judicial inertia which results in the unauthorized assumption by an agency of major policy decisions properly made by Congress." 104

As Mr. Justice White underscores, the Court now treats as mere lip service the declarations in Buffalo Linen and Erie Resistor that the Board has primary responsibility in the "delicate task ... of weighing the interests." The Board is relegated to a mere fact finder, not competent to give the Court guidance in resolving the difficult issues of policy.

The Court's lack of confidence in the Board may explain, at least in part, its decisions in the Anti-Trust Cases. The Court's obvious alternative to continued involvement was to find that the problems are now regulated by the National Labor Relations Act and that primary jurisdiction is in the Board. But a Court which two months before would give no deference to the Board's weighing of interests under its own statute could not seriously consider entrusting the Board with working out an accommodation between that statute and the anti-trust laws.

Why has the Court seemingly lost confidence in the Board? The reasons are undoubtedly complex and too deep to be probed here, but the cases this year suggest some cause for judicial distrust. Fibreboard alone was enough to cause the Court to cast a jaundiced eye on the Board's expertise. The Board had first firmly declared that in its judgment the decision to subcontract in this case was not a mandatory subject. ${ }^{105}$ After a change of administration had changed the membership of the Board, the case was reconsidered and the new Board with equal firmness found that it was a mandatory subject. ${ }^{106}$ It would indeed have been awkward for the Court to give deference to such ex-

103. 380 U.S. 263, 272 (1965).

104. NLRB v. Brown, 380 U.S. 278, 292 (1965)

105. 130 N.L.R.B. 1558, 1561 (1961).

106. 138 N.L.R.B. 550-51 (1962). 
pertise. The Court could not help knowing that other cases-cases which raised substantial issues of policy on which the Court might want and need guidance-had been similarly reversed by a hair-breadth national election. ${ }^{107}$ Nor was this a new condition, for in 1952 also an election brought changes in Board membership and changes in the law. ${ }^{108}$ Among those changes, as the Court knew, was a change in the Board's decisions on lockouts. ${ }^{109}$ Judgment which bends with the political winds cannot command much confidence in the Court, nor are claims of industrial experience and expertise under such circumstances given full faith and credit.

Another factor which makes the Court unwilling, if not unable, to look to the Board for guidance is that the Board in its opinions seeks too seldom to illuminate and too often to obscure. The rank example is $N L R B$ v. Metropolitan Life Insurance Co. ${ }^{110}$ where the Board's determination of appropriate units for insurance agents was challenged on the grounds that the units were based solely on the extent of organization in violation of Section 9(c)(5). The Board gave no reason for its decision other than the citation of certain other insurance agents cases which were not directly relevant and omitted citation of other cases which seemed contrary. The Board's opinion was so confusing and inadequate that the Court was unable to review and was forced to remand the case to the Board. The problem was critical in many service industries with spotty organization. The Board was apparently parcelling units so as to permit those who sought representation to have collective bargaining but not expanding units so as to encompass groups who did not seek representation. It was thus providing both the encouragement of collective bargaining and the maximum freedom of

107. See, for example, International Hod Carriers, Local 840 (Blinne Construction), 130 N.L.R.B. 587 (1961), opinion withdrawn and new opinion substituted, 135 N.L.R.B. 1153 (1962); Hotel and Restaurant Employees Union (Crown Cafeteria), 130 N.L.R.B. 570 (1961), reconsidered and dissenting opinion in preceding case adopted as majority opinion 135 N.L.R.B. 1183 (1962).

108. See, for example, Breeding Transfer Co., 110 N.L.R.B. 493 (1954), Livingstone Shirt Corp., 107 N.L.R.B. 400 (1954); Pacific Intermountain Express Co., 107 N.L.R.B. 837 (1954).

109. The "Old Board's" decision in Davis Furniture Co., 100 N.L.R.B. 1016 (1952) was reversed by the Court of Appeals in Leonard v. NRLB, 205 F.2d 355 (9th Cir. 1953). The "Eisenhower Board" declined to petition for certiorari, the Chairman stating that the Board thought there was nothing unlawful in the employer's conduct. 33 L.R.R.M. 100. The Board's wavering body of law came before the Court in the Buffalo Linen case, 353 U.S. 87 (1953). The Court recalled these Board changes in American Ship Building, 380 U.S. at 307, n.7.

110. 380 U.S. 438 (1965). 
choice by the individual - thereby effectuating two fundamental statutory policies. But however good its reasons, they could not be known, much less given weight by the Court. This example is extreme but indicative. The Fibreboard ${ }^{111}$ opinions contained no exploration of the purpose of the duty to bargain, no study of bargaining practices, and no helpful projection of where proposed solutions might lead. It was a battle of Board and Court precedents as if the issue were one of consistency with past poorly considered decisions rather than one of designing solutions to fit an evolving bargaining structure. Similarly, the Darlington ${ }^{112}$ opinions say nothing of the potential dangers of plant closings or of threats made during the election campaign. From all the Board says, these may be insubstantial matters, for the opinions again devote themselves to parsing of precedents. Why should the Court look to the Board for guidance? Each of the justices have two law clerks who can read the cases perhaps even better than the Board.

The picture drawn from the major labor law decisions this year is one of the Supreme Court as the chief lawgiver. This is, of course, a caricature, for the bulk of the cases, even in labor law, raise at best subordinate questions of policy, and their decision is guided if not governed by articulate Congressional policies or understandable statutory words. But the picture, as a caricature, emphasizes certain features of our lawmaking process. On certain problems which reach close to the core of our national labor policy, Congress has failed or refused to act; Congress has simply not resolved basic issues of policy. The number of these is greater than the complexity of our statutes might suggest, for as the Clayton Act teaches, the absence of decision is often hidden by the plethora of words. Though we have a Board which is created to bring experience, judgment, expertness and institutional resources to bear on these problems and to serve as an intermediary in evolving solutions, it does not serve that function. The responsibility for weighing the values and shaping the institutions of collective bargaining comes to rest upon the Court.

The purpose here is not to assess blame. We cannot blame Congress for its default without asking why in enacting labor legislation it behaves in this fashion. Nor can we blame the Board without probing for the forces which have weakened its ability to perform. Nor is the Court a wholly innocent victim, for it has seldom protected against its power, insisted on Congressional action, or encouraged the Board to

111. 130 N.L.R.B. 1558 (1961); 138 N.L.R.B. 550 (1962).

112. 139 N.L.R.B. 241 (1962). 
broaden its considerations. The purpose here is simply to try to make plain how our labor law is being made. Underneath is the unproven assumption that this is not the way to run a government, and a subtle suggestion that it is time for a serious consideration of major changes in the administration of our labor lawmaking process. 